\title{
USPOREDBA ANKSIOZNOSTI I DEPRESIVNOSTI U ONKOLOŠKIH PACIJENATA LIJEČENIH KEMOTERAPIJOM I ZRAČENJEM
}

\author{
Ivona Hrkać, Marko Pavlović, Shpend Haxhibeqiri, Romana Babić, Marko Martinac, Dragan Babić \\ Fakultet zdravstvenih studija Sveučilišta u Mostaru, 88000 Mostar, Bosna i Hercegovina \\ Rad je primljen 29.01.2019. Rad je recenziran 12.02.2019. Rad je prihvaćen 11.03.2019.
}

\section{SAŽETAK}

UVOD: Dijagnoza maligne bolesti jedna je od najtežih dijagnoza, praćena je društvenim predrasudama i izaziva velik strah u bolesnika i njihovih obitelji. Ljudi koji žive s malignom bolesti imaju veći rizik za razvoj različitih psihičkih problema. CILJ: Usporediti anksioznost i depresivnost u onkoloških pacijenataliječenih kemoterapijom i zračenjem.

ISPITANICI I POSTUPCI: U istraživanju je sudjelovalo 60 pacijenata. Podaci su prikupljeni dragovoljno na Klinici za onkologiju Sveučilišne kliničke bolnice Mostar pomoću Beckovih upitnika za anksioznost (BAI) i depresiju (BDI-II) te općeg sociodemografskog upitnika.

REZULTATI: Ispitanici u skupini s kemoterapijom su bili statistički značajno lošijeg ekonomskog statusa i u višem postotku su bili pušači.Ispitanici muškog spola su bili značajno stariji od žena, dok su žene postizale značajno viši rezultat na skali depresivnosti. U razini anksioznosti nije bilo statistički značajnih razlika među spolovima. Nije bilo statistički značajnih povezanosti između stupnja anksioznosti i depresivnosti s brojem hospitalizacija.

Ispitanici u skupini s kemoterapijom su postizali statistički značajno više rezultate anksioznosti.Nije bilo statistički značajnih razlika u stupnju depresivnostimeđu ispitivanim skupinama.

ZAKLJUČAK: Ispitanici u skupini s kemoterapijom postizali statistički značajno više rezultate na skali anksioznosti.Nije bilo statistički značajnih razlika u stupnju depresivnostimeđu ispitivanim skupinama

KLJUČNE RIJEČI: anksioznost, depresivnost, onkološki pacijent, liječenje

Osoba za razmjenu informacija:

Ivona Hrkać, magistar radiološke tehnologije

E-mail: ivonahrkac@gmail.com

Prof. dr. sc. Dragan Babić

E-mail: dragan.babic@fzs.sum.ba 


\section{UVOD}

Anksioznost ili tjeskoba može se opisati kao osjećaj opće napetosti, zabrinutosti, velikog stresa, panike ili straha, a javlja se kada je osoba izložena nekoj stvarnoj ili izmišljenoj prijetećoj situaciji. Očituje se fizičkim i psihičkim simptomima koje osoba doživljava kao izrazito neugodne. Anksioznost je sastavni dio života i u njemu ima adaptivnu funkciju, no ona postaje poremećaj onda kada je neprestano prisutna u životu pojedinca te kada se javlja u neuobičajenim situacijama (npr. u sredstvima javnog prijevoza ili u liftu te u društvenim interakcijama). Anksioznost tada značajno ograničava osobu u svakodnevnom funkcioniranju i profesionalnom ostvarenju, čime umanjuje kvalitetu života (1).

Depresivno raspoloženje karakterizira potištenost, vidan pad energije, interesa i volje, poteškoće koncentracije, promjena sna, apetita i težine, osjećanje krivice ili bezvrijednosti, misli o smrti ili suicidu. Depresija se ubraja ne samo u najranije opisane bolesti u povijesti medicine, nego i u najčešće psihičke poremećaje. Depresija je bolest našeg vremena i predstavlja veliki izazov, ne samo za profesionalce u oblasti mentalnog zdravlja, već i za obiteljske liječnike. Visoka stopa morbiditeta i mortaliteta i čest komorbiditet samo su neke od karakteristika depresivnih poremećaja. Sve ovo postavlja pred liječnike u primarnoj zdravstvenoj zaštiti važan zadatak da znaju da prepoznaju depresivne poremećaje, da neke od njih liječe, a druge pravovremeno upute na specijalističko liječenje (2).

Rak je bolest koja zbog svoje težine i ozbiljnosti može imati snažan utjecaj na psihičko stanje bolesnika (3). Dijagnoza maligne bolesti jedna je od najtežih dijagnoza, praćena je društvenim predrasudama i izaziva velik strah u bolesnika i njihovih obitelji (4). Ljudi koji žive s malignom bolesti imaju veći rizik za razvoj različitih psihičkih problema. Istraživanja pokazuju da takvi bolesnici pate ne samo od fizičkih simptoma bolesti, nego i od psihološkog i društvenog stresa koji je povezan s dijagnozom. Istraživanja govore da se osim straha od umiranja, pacijenti osjećaju ugroženi intervencijama, poput kemo ili radio-terapije, brinu o gubljenju njihova tjelesnog integriteta, neovisnosti i društvenih uloga (5).

Cilj ovog istraživanja bio je utvrditi stupanj anksioznosti i depresivnosti u onkoloških pacijenata te utvrditi razlikuje li se stupanj anksioznosti i depresivnosti u pacijenata liječenih zračenjem i kemoterapijom kao i postoji li korelacija stupnja anksioznosti i depresivnosti s duljinom trajanja liječenja.

\section{ISPITANICI I POSTUPCI}

Istraživanje se provodilo u Klinici za onkologiju Sveučilišne kliničke bolnice Mostar. Ispitivani uzorak činilo je 60 pacijenata koji se liječe kemoterapijom i zračenjem životne dobi od 18 do 65 godina. Ispitivanu skupinu činilo je 30 pacijenata koji su podvrgnuti samo kemoterapiji, a kontrolnu skupinu činili su pacijenti koji su podvrgnuti samo radioterapiji.

U istraživanju se koristila anketa sa socio-demografskim karakteristikama, gdje su ispitanici trebali napisati svoju dob, spol, bračni status i stupanj obrazovanja. Ispitanicima su se detaljno objasnili ciljevi i namjere ispitivanja, kao i činjenica da su prikupljeni podaci tajni i da će se koristiti isključivo u svrhu izrade diplomskog rada.

Kriteriji za uključivanje u istraživanje:

- dijagnosticirana maligna bolest;

- muška i ženska populacija;

- životna dob ispitanika 18-65 godina;

- ispitanici koji su dobrovoljno pristali sudjelovati u istraživanju.

Kriteriji za isključivanje iz istraživanja:

- bolesnici s poznatom psihijatrijskom bolesti;

- ispitanici koji nisu htjeli dobrovoljno sudjelovati u istraživanju;

- ispitanici koji su nepravilno/nepotpuno ispunili upitnike.

Istraživanje se provodilo primjenom upitnika:

a) Beckova skala depresivnosti BDI-II (engl. Beck Depression Inventory)

b) Beckov registar anksioznosti BAI (engl. Beck Anxiety Inventory)

c) opći sociodemografski upitnik 
Beckovi upitnici za depresiju i anksioznost autora Aarona T. Becka standardizirani su samoocjenski upitnici s mogućnošću višestrukog izbora od kojih svaki sadržava po 21 pitanje. Pitanja su vezana za depresivne i anksiozne simptome, a na temelju ispitanikovih odgovora i konačnog rezultata ispitanik se klasificira u određenu kategoriju temeljenu na stupnju intenziteta depresije i anksioznosti (6).

1. Upitnik BDI-II sadrži 21 česticu pomoću kojih se procjenjuje težina depresije kod odraslih i adolescenata. Od sudionika se traži da za svaku česticu izabere jedan od ponuđenih odgovora koji se odnosi na vlastito osjećanje i ponašanje u zadnja dva tjedna, uključujući i trenutak ispitivanja. Odgovori se boduju na skali od 4 stupnja (0 - 3). Rezultat u rasponu od 0 do 13 bodova upućuje na odsustvo, odnosno minimalnu razinu depresije; od 14 do 19 smatra se blagom depresijom; od 20 do 28 umjerenom, dok su rezultati iznad 29 u kategoriji teške depresije.

2. Upitnik BAI dizajniran je kao instrument za mjerenje generalizirane anksioznosti i razlikovanje simptoma anksioznosti od depresije. Ima 21 česticu, na koju ispitanik odgovara na ljestvici od 0 do 3 ( 0 = nema, 3 = jako izraženo). Ukupni rezultat ljestvice upućuje na stupanj anksioznosti - veći rezultat znači veći intenzitet anksioznosti. Može se koristiti i za procjenu promjene simptoma anksioznosti tijekom liječenja. S ljestvicom postoje dobra klinička iskustva i u svakodnevnoj kliničkoj praksi, poglavito zbog jednostavnosti primjene.

\section{Statistička obrada}

Dobiveni rezultati su obrađeni pomoću deskriptivnih, te neparametrijskih i parametrijskih metoda inferencijalne statistike ovisno o distribuciji podataka. Distribucija uzorka za svaku kontinuiranu varijablu i za svaku istraživanu skupinu je testirana Kolmogorov-Smirnovim testom. Kategorijske varijable su prikazane deskriptivno statistički kao frekvencija i postotak dok su kontinuirane varijable prikazivane kao aritmetička sredina i standardna devijacija. Razlike u kategorijskim varijablama testirane su hi kvadrat testom i Fisherovim egzaktnim testom gdje je to bilo potrebno. Razlike među kontinuiranim varijablama su testirane Student t-testom. Za testiranje povezanosti među varijablama korišteni su Pearsonov i Spearmanov test korelacije. Razina vjerojatnosti od $\mathrm{p}<0,05$ se uzela kao statistički značajna.

SPSS statistički softver, verzija 17 , je korišten za sve statističke analize (SSPS Inc., Chicago, IL).

\section{REZULTATI}

U tablici 1 prikazane su sociodemografske karakteristike uzorka. Ispitanici u skupini s kemoterapijom su bili statistički značajno lošijeg ekonomskog statusa i u višem postotku su bili pušači, u ostalim varijablama prikazanim u tablici 1 nije bilo statistički značajnih razlika među skupinama.

Tablica 1. Sociodemografske karakteristike uzorka

\begin{tabular}{|c|c|c|c|c|c|c|}
\hline & \multicolumn{4}{|c|}{ Skupina } & \multirow{3}{*}{$x^{2}$} & \multirow[t]{3}{*}{$\mathrm{p}$} \\
\hline & \multicolumn{2}{|c|}{ Kemoterapija } & \multicolumn{2}{|c|}{ Zračenje } & & \\
\hline & $\mathrm{N}$ & $\%$ & $\mathrm{~N}$ & $\%$ & & \\
\hline Spol & & & & & 0,274 & 0,600 \\
\hline M & 14 & 46,7 & 11 & 36,7 & & \\
\hline Ž & 16 & 53,3 & 19 & 63,3 & & \\
\hline Radni status & & & & & 3,411 & 0,182 \\
\hline Zaposlen & 7 & 23,3 & 10 & 33,3 & & \\
\hline Nezaposlen & 10 & 33,3 & 4 & 13,3 & & \\
\hline Umirovljenik & 13 & 43,3 & 16 & 53,3 & & \\
\hline Obrazovanje & & & & & 4,173 & $0,259^{*}$ \\
\hline OŠ & 6 & 20,0 & 5 & 16,7 & & \\
\hline SSS & 18 & 60,0 & 16 & 53,3 & & \\
\hline VŠS & 5 & 16,7 & 3 & 10,0 & & \\
\hline VSS & 1 & 3,3 & 6 & 20,0 & & \\
\hline Brak & & & & & 0,326 & $1^{*}$ \\
\hline Oženjen & 26 & 86,7 & 26 & 86,7 & & \\
\hline Neoženjen & 1 & 3,3 & 1 & 3,3 & & \\
\hline Udovac & 3 & 10,0 & 3 & 10,0 & & \\
\hline $\begin{array}{l}\text { Mjesto } \\
\text { boravka }\end{array}$ & & & & & 0,068 & 0,794 \\
\hline Selo & 14 & 46,7 & 12 & 40,0 & & \\
\hline Grad & 16 & 53,3 & 18 & 60,0 & & \\
\hline $\begin{array}{l}\text { Ekonomski } \\
\text { status }\end{array}$ & & & & & 6,547 & $0,042^{\star}$ \\
\hline Loš & 3 & 10,0 & 0 & 0,0 & & \\
\hline Srednji & 23 & 76,7 & 21 & 70,0 & & \\
\hline Vrlo dobar & 3 & 10,0 & 9 & 30,0 & & \\
\hline
\end{tabular}


Hrkać I, Pavlović M, Haxhibeqiri S, Babić R, Martinac M, Babić D, Usporedba anksioznosti i depresivnosti u onkoloških pacijenata liječenih kemoterapijom i zračenjem. Zdravstveni glasnik. 2019; 5(1): 40-47

\begin{tabular}{|l|l|l|l|l|l|l|}
\hline Odličan & 1 & 3,3 & 0 & 0,0 & & \\
\hline Pušenje & 12 & 40,0 & 4 & 13,3 & 4,146 & $\mathbf{0 , 0 4 1}$ \\
\hline Alkohol & 9 & 30,0 & 5 & 16,7 & 0,839 & 0,360 \\
\hline $\begin{array}{l}{ }^{*} \text { Fisherov } \\
\text { egzaktni test }\end{array}$ & & & & & & \\
\hline
\end{tabular}

$\mathrm{U}$ tablici 2 prikazane su razlike u dobi i rezultatima postignutim na skalama depresivnosti i anksioznosti među skupinama. Ispitanici u skupini s kemoterapijom su postizali statistički značajno više rezultate na BAI skali, u ostalim varijablama prikazanim u tablici 2 nije bilo statistički značajnih razlika među skupinama.

Tablica 2. Razlike u dobi i rezultatima postignutim na skalama depresivnosti i anksioznosti među skupinama

\begin{tabular}{|c|c|c|c|c|c|c|}
\hline & Skupir & & & & & \\
\hline & Kemo & rapija & Zračes & & $t$ & $\mathrm{p}$ \\
\hline & $\bar{X}$ & SD & $\bar{X}$ & SD & & \\
\hline Dob & 54,87 & 13,15 & 60,33 & 11,89 & 1,689 & 0,097 \\
\hline BAI & 9,17 & 7,60 & 5,77 & 4,92 & 2,057 & 0,044 \\
\hline BDI & 9,17 & 6,37 & 6,20 & 7,27 & 1,681 & 0,098 \\
\hline
\end{tabular}

$\mathrm{U}$ tablici 3 prikazane su razlike u stupnju depresivnosti među skupinama. Nije bilo statistički značajnih razlika u stupnju depresivnosti među skupinama.

Tablica 3.Razlike u stupnju depresivnosti među skupinama

\begin{tabular}{|l|l|l|l|l|l|l|}
\hline & \multicolumn{3}{|l|}{ Skupina } & \multirow{2}{*}{$\chi^{2}$} & $\mathrm{p}$ \\
\cline { 2 - 7 } & Kemoterapija & Zračenje & & \\
\cline { 2 - 7 } & $\mathrm{N}$ & $\%$ & $\mathrm{~N}$ & $\%$ & & \\
\hline BDI & & & & & 4,863 & $0,169^{*}$ \\
\hline Bez depresije & 22 & 73,3 & 27 & 90,0 & & \\
\hline $\begin{array}{l}\text { Depresija } \\
\text { blagog } \\
\text { intenziteta }\end{array}$ & 5 & 16,7 & 1 & 3,3 & & \\
\hline $\begin{array}{l}\text { Depresija } \\
\text { umjerenog } \\
\text { intenziteta }\end{array}$ & 3 & 10,0 & 1 & 3,3 & & \\
\hline $\begin{array}{l}\text { Depresija } \\
\text { jako izražena }\end{array}$ & 0 & 0,0 & 1 & 3,3 & & \\
\hline $\begin{array}{l}\text { *Fisherov } \\
\text { egzaktni test }\end{array}$ & & & & & & \\
\hline
\end{tabular}

U tablici 4 prikazane su razlike u stupnju depresivnosti među spolovima. Nije bilo statistički značajnih razlika u stupnju depresivnosti među spolovima.

Tablica 4. Razlike u stupnju depresivnosti među spolovima

\begin{tabular}{|c|c|c|c|c|c|c|}
\hline & \multicolumn{4}{|c|}{ Spol } & \multirow[t]{3}{*}{$\chi^{2}$} & \multirow[t]{3}{*}{$\mathrm{p}$} \\
\hline & \multicolumn{2}{|c|}{$\mathrm{M}$} & \multicolumn{2}{|l|}{$\check{Z}$} & & \\
\hline & $\mathrm{N}$ & $\%$ & $\mathrm{~N}$ & $\%$ & & \\
\hline $\mathrm{BDI}$ & & & & & 3,666 & $0,266^{*}$ \\
\hline Bez depresije & 22 & 88,0 & 27 & 77,1 & & \\
\hline $\begin{array}{l}\text { Depresija } \\
\text { blagog } \\
\text { intenziteta }\end{array}$ & 3 & 12,0 & 3 & 8,6 & & \\
\hline $\begin{array}{l}\text { Depresija } \\
\text { umjerenog } \\
\text { intenziteta }\end{array}$ & 0 & 0,0 & 4 & 11,4 & & \\
\hline $\begin{array}{l}\text { Depresija jako } \\
\text { izražena }\end{array}$ & 0 & 0,0 & 1 & 2,9 & & \\
\hline $\begin{array}{l}{ }^{*} \text { Fisherov } \\
\text { egzaktni test }\end{array}$ & & & & & & \\
\hline
\end{tabular}

U tablici 5 prikazane su razlike u dobi i rezultatima postignutim na skalama depresivnosti i anksioznosti među spolovima. Ispitanici muškog spola su bili značajno stariji od žena, dok su žene postizale značajno viši rezultat na skali depresivnosti, dok u razini anksioznosti nije bilo statistički značajnih razlika među spolovima.

Tablica 5. Razlike u dobi i rezultatima postignutim na skalama depresivnosti i anksioznosti među spolovima

\begin{tabular}{|c|c|c|c|c|c|c|}
\hline & \multicolumn{4}{|l|}{ Spol } & \multirow[b]{2}{*}{$\mathrm{T}$} & \multirow[b]{2}{*}{$p$} \\
\hline & \multicolumn{2}{|l|}{$\mathrm{M}$} & \multicolumn{2}{|l|}{ Ž } & & \\
\hline & $\bar{X}$ & SD & $\bar{X}$ & SD & & \\
\hline Dob & 65,52 & 10,70 & 51,94 & 11,01 & 4,764 & $<0,001$ \\
\hline BAI & 5,72 & 5,29 & 8,71 & 7,17 & 1,770 & 0,082 \\
\hline BDI & 4,96 & 4,69 & 9,63 & 7,66 & 2,920 & 0,005 \\
\hline
\end{tabular}

U tablici broj 6 prikazana je povezanost između stupnja anksioznosti i depresivnosti s hospitalnim liječenjem. Nije bilo statistički značajnih povezanosti između stupnja anksioznosti i depresivnosti s hospitalnim liječenjem. 
Tablica 6. Povezanost između stupnja anksioznosti i depresivnosti s hospitalnim liječenjem

\begin{tabular}{|l|l|l|}
\hline \multirow{2}{*}{} & \multicolumn{1}{|l|}{ Hospitalizacija } \\
\cline { 2 - 3 } & $\mathrm{r}$ & $\mathrm{p}$ \\
\hline BAI & $-0,097$ & 0,461 \\
BDI & $-0,181$ & 0,166 \\
\hline
\end{tabular}

U tablici 7 prikazana je povezanost imeđu stupnja anksioznosti i depresivnosti s brojem hospitalizacija. Nije bilo statistički značajnih povezanosti između stupnja anksioznosti i depresivnosti s brojem hospitalizacija.

Tablica 7. Povezanost između stupnja anksioznosti i depresivnosti s brojem hospitalizacija

\begin{tabular}{|l|l|l|}
\hline \multirow{2}{*}{} & \multicolumn{2}{|l|}{ Broj hospitalizacija } \\
\cline { 2 - 3 } & $\rho$ & $\mathrm{p}$ \\
\hline BAI & 0,078 & 0,731 \\
BDI & 0,229 & 0,306 \\
\hline
\end{tabular}

\section{RASPRAVA}

Ispitanici u skupini s kemoterapijom su bili statistički značajno lošijeg ekonomskog statusa i u višem postotku su bili pušači te su postizali značajno više rezultate na BAI skali. Ispitanici muškog spola su bili značajno stariji od žena, dok su žene postizale značajno viši rezultat na skali depresivnosti. U razini anksioznosti nije bilo statistički značajnih razlika među spolovima. Nije bilo statistički značajnih razlika u stupnju depresivnosti među skupinama ni statistički značajnih povezanosti između stupnja anksioznosti i depresivnosti s hospitalnim liječenjem i brojem hospitalizacija. Korelacija stupnja anksioznosti i depresivnosti s duljinom trajanja liječenja koja je postavljena u cilju broj 3 nije bila statistički izvediva jer je liječenje obilježeno kategorijski samo za dio ispitanika pa je odrađena povezanost $s$ brojem hospitalizacija koja nije pokazala statistički značajne razlike između skupina.

Anksioznost i depresivnost te psihičke simptome onkoloških pacijenata ispitivali su i mnogi drugi istraživači.

U radu Vukojević i sur. ispitivana je anksioznost i depresivnost kod onkoloških bolesnika na odjelu onkologije Sveučilišne kliničke bolnice Mostar. U istraživanje je bilo uključeno 160 bolesnika, koji su bili podijeljeni u dvije skupine: ispitnu i kontrolnu. Svakom bolesniku iz ispitne skupine bio je pridružen bolesnik iz kontrolne skupine prema dobi, spolu, stupnju naobrazbe i bračnom statusu. Ispitnu skupinu činilo je 80 bolesnika koji su se liječili na odjelu onkologije Sveučilišne kliničke bolnice Mostar. Kontrolnu skupinu činilo je 80 bolesnika koji su primljeni u ordinaciju obiteljske medicine Doma zdravlja Mostar. Ispitna je skupina pokazala statistički viši stupanj depresivnosti, dok za anksioznost nije utvrđena statistički značajna razlika između ispitne i kontrolne skupine (7).

U radu koji je urađen na Zavodu za onkologiju i radioterapiju Kliničkog bolničkog centra u Splituispitivana je učestalost depresije među onkološkim bolesnicama koje boluju od karcinoma dojke. Rezultati su pokazali statistički značajno veću učestalost depresije u cijeloj skupini ispitanica koje boluju od karcinoma dojke (24,56\%) naspram prevalencije depresije kod žena u općoj populaciji (10-12\%). Među rezultatima najučestalija je blaga depresija $(15,79 \%)$, zatim slijedi umjerena depresija (5,26 \%) te teška depresija (3,51 \%). Iako je iz rezultata vidljivo da je depresija uočena u većoj mjeri u skupini bolesnica koje su na kemoterapiji $(29,41 \%)$ od bolesnica koje su na praćenju po završetku aktivne terapije (17,39\%), nažalost ta razlika nije statistički značajna i autori nisu uspjeli dokazati da je udio depresije veći kod žena koje su na kemoterapiji (8).

$\mathrm{Na}$ Klinici za onkologiju Sveučilišne kliničke bolnice Mostar provedeno je ispitivanje kvalitete života i psihičkih simptoma u onkoloških pacijenata liječenih kemoterapijom i zračenjem. Ispitivani uzorak tvorilo je 60 bolesnika koji su na provedbi kemoterapijskog i radioterapijskog liječenja. Za mjerenje kvalitete života koristio se Upitnik kvalitete života Svjetske zdravstvene organizacije (SZO) WHOQOL-BREF ljestvica. Za procjenu psihičkih simptoma koristila se Ljestvica samoprocjene SCL90. Zaključeno je da su onkološki bolesnici liječeni zračenjem statistički značajno većom ocjenom procjenjivali svoje zadovoljstvo zdravljem i imali su manju učestalost psihičkih simptoma u odnosu na bolesnike liječene kemoterapijom (9). 
$\mathrm{Na}$ Zavodu za torakalnu, plastičnu i rekonstrukcijsku kirurgiju u Kliničkom bolničkom centru Osijek provedeno je istraživanje o utjecaju operativnog zahvata na sliku o sebi u žena s karcinomom dojke. Istraživanje je provedeno na 354 ispitanice, 178 oboljelih od karcinoma dojke, te 176 zdravih ispitanica, po dobi sukladnih oboljelima. Istraživanje je provedeno pomoću upitnika koji se sastojao od sociodemografskog upitnika te validiranih skala za odredivanje slike o sebi, razine depresije, anksioznosti i stresa, te razine socijalne podrške. Bolesnice s nižom razinom socijalne podrške imale su lošiju sliku o sebi, te više razine depresije, anksioznosti i stresa. Bolesnice s lošijom slikom o sebi imale su više razine depresije, anksioznosti i stresa. Snažna socijalna podrška utjecala je na poboljšanje slike o sebi i smanjenje razina depresije, anksioznosti i stresa (10).

U istraživanju koje je provedeno u Psihoonkološkom savjetovalištu Opće Bolnice Pula je sudjelovalo ukupno 58 ispitanika, 47 ženskih i 11 muških bolesnika. Raspon dobi kretao se od 31 do 88 godina starosti ispitanika. $\mathrm{U}$ intervencijsku studiju uključeni su bolesnici kod kojih je bila indicirana psihoonkološka pomoć kao i oni koji su dobrovoljno pristali na navedeni tretman. U kontrolnoj skupini bili su bolesnici koji nisu primili psihoonkološki tertman. T-testom za velike ovisne uzorke ustanovljena je statistički značajna razlika u anksioznosti i depresivnosti ispitanika prije i poslije terapije $(\mathrm{t}=3,88, \mathrm{SS}=$ $57, \mathrm{p}<0.01)$. Ispitanici su imali značajno nižu razinu anksioznosti i značajno nižu razinu depresivnosti nakon 6 mjeseci terapije (11).

U istraživanju koje je provedeno na području Šibensko-kninske i Zadarske županije sudjelovale su 84 osobe oboljele od raka. Cilj istraživanja je bio ispitati odnos strategija suočavanja pacijenta te percepcije vlastite bolesti i kvalitete života, anksioznosti i depresivnosti te osobe. Rezultati su pokazali kako pojedini aspekti percepcije bolesti imaju značajan doprinos objašnjenju kvalitete života, anksioznosti i depresivnosti onkoloških pacijenata. Percepcija viših razina emocionalnih reprezentacija predviđa više razine anksioznosti, dok percepcija viših razina emocionalnih reprezentacija i ozbiljnijih posljedica bolesti (značajan utjecaj bolesti na financijsko stanje, život općenito) predviđa više razine depresivnosti pacijenta. Također, dobiveno je kako strategije suočavanja nisu u korelaciji s kvalitetom života, anksioznošću i depresivnošću (12).

Istraživanje koje je provodila Burgess ispitivajući depresiju i anksioznost kod žena s rakom dojke pokazuje kako je incidencija depresije i anksioznosti u onkoloških bolesnika tri puta veća nego u općoj populaciji te varira od $43,5 \%$ do $60 \%$. Najveća incidencija depresije utvrđena je kod bolesnika s karcinomom gušterače i pluća, a najmanja incidencija kod bolesnika koji su oboljeli od kožnih karcinoma. U onkoloških bolesnika dob, spol, materijalni status i stupanj obrazovanja nemaju nikakvu ulogu kod intenziteta depresije i anksioznosti (13).

Istraživanje provedeno u Njemačkoj o dugotrajnom preživljavanju oboljelih od hematoloških karcinoma pokazuje da je depresija, više nego anksioznost, istaknuti problem. Rezultati ukazuju na važnost praćenja pacijenata čak i godinama nakon dijagnosticiranja i pružanja psihosocijalne podrške pacijentima u potrebi (14).

U istraživanju koje je provedeno na Norwegian Radium Hospital dobiveno je da je prevalencija anksioznosti i depresije kod 716 procjenjivanih bolesnika bila $13 \%$ odnosno $9 \%$, prema procjeni HADS. Žene su imale znatno višu razinu anksioznosti od muškaraca. Bolesnici mlađi od 30 ili stariji od 70 godina izrazili su manju anksioznost od ostalih pacijenata. Dob ili spol nisu utjecali na pojavu depresije. Oslabljena sposobnost nastavka profesionalnog rada ili svakodnevnih životnih aktivnosti, oslabljen društveni život i prethodni psihijatrijski problemi bili su značajno povezani s anksioznošću i depresijom. Potrebno je posvetiti posebnu pozornost pacijentima s rakom koji pokazuju te probleme kako bi dijagnosticirali i liječili depresiju i anksiozne poremećaje (15).

\section{ZAKLJUČCI}

Žene su postizale značajno viši rezultat na skali depresivnosti, dok u razini anksioznosti nije bilo statistički značajnih razlika među spolovima.Nije bilo statistički značajnih razlika u stupnju depresivnosti među skupinama, ali su ispitanici u skupini s 
kemoterapijom postizali statistički značajno više rezultate na skali anksioznosti.Korelacija stupnja anksioznosti i depresivnosti s duljinom trajanja liječenja koja je postavljena u cilju broj 3 nije bila izvediva jer je liječenje obilježeno kategorijski samo za dio ispitanika pa je odrađena povezanost s brojem hospitalizacija koja nije pokazala statistički značajne razlike između skupina.

\section{LITERATURA}

1. Jelavić S. Kako liječiti anksioznost. Pliva zdravlje. [Online]2015. [pristupljeno 26.11.2018.] Dostupno na: http://www.plivazdravlje.hr/aktualno/clanak/26203/Kako-lijeciti-anksioznost. html

2. Depresija i distimija - klinički vodič. Mentalno zdravlje. [pristupljeno 26.11.2018. ] Dostupno na: http://www.mentalnozdravlje.ba/uimages/ pdf/depresijaidistimija.pdf

3. Braš $M$. Epidemiologija i kliničke slike najčešćih psihijatrijskih poremećaja u onkologiji. U: Gregurek R, Braš M, ur. Psihoonkologija. Osijek: Grafika d.o.o.; 2008. str. 51-78.

4. Dobrila-Dintinjana $\mathrm{R}$, Vukelić J, Dintinjana M. Liječenje maligne boli. Medicus [Online]. 2014. [pristupljeno 26.11.2018.];23(2. Liječenje boli):93-98. Dostupno na: https://hrcak.srce. $\mathrm{hr} / 127301$

5. Barre VP, Padmaja G, Saxena RK, Rana S. Impact of medical intervention on stress and quality of life in patients with cancer. Indian J Palliat Care. 2015;21:203-8.

6. Hotujac Lj, Filipcic I, Grubišin J, Marcinko D. Živjeti s depresijom. PLIVA,2003.

7. Vukojević M, Perić I, Kordić M. Anksioznost i depresivnost kod onkoloških bolesnika u Sveučilišnoj kliničkoj bolnici Mostar. Liječnički vjesnik [Online]. 2012. [pristupljeno 14.1.2019.];134(7-8):0-0. Dostupno na: https:// hrcak.srce.hr/172434

8. Antunović D. Depresija u onkoloških bolesnika [Diplomski rad]. Split: Sveučilište u Splitu, Medicinski fakultet; 2017. [pristupljeno 14.1.2019.] Dostupno na: https://urn.nsk.hr/urn:nbn:hr:171:168218
9. Bačić M. Usporedba kvalitete života i psihičkih simptoma u onkoloških pacijenata liječenih kemoterapijom i zračenjem. Mostar: Sveučilište u Mostar, Fakultet zdravstvenih studija; 2018.

10. Šijan I. Utjecaj operativnog zahvata na sliku o sebi u žena s karcionomom dojke [Diplomski rad]. Osijek: Sveučilište Josipa Jurja Strossmayera, Medicinski fakultet; 2016 [pristupljeno 14.1.2019.] Dostupno na: https://urn.nsk.hr/urn:nbn:hr:152:137837

11. Peharda T, Trivanović D. Multidisciplinarni pristup onkološkim pacijentima u OB Pula. Glasnik pulske bolnice [Online]. 2009. [pristupljeno 14.1.2019.];6(6):140-142. Dostupno na: https://hrcak.srce.hr/46119

12. Reljić A. Suočavanje s bolešću i kvaliteta života onkoloških bolesnika [Diplomski rad] Zadar: Sveučilište u Zadru; 2018. [pristupljeno 14.1.2019.] Dostupno na: https://urn.nsk.hr/ urn:nbn:hr:162:831490

13. Burgess C, Cornelius V, Love S, Graham J, Richards M, Ramirez A. Depression and anxiety in women with early breast cancer: five year observational cohort study. BMJ. 330: 702

14. Kuba K.Risk for depression and anxiety in longterm survivors of hematologic cancer. Health Psychol. 2019 Mar;38(3):187-195. doi: 10.1037/ hea0000713.

15. Aass N, Fossa SD, Dahl AA and Moe TJ. Prevalence of anxiety and depression in cancer patients seen at the Norwegian Radium Hospital. Eur J Cancer 1997;33: 1597-1604 


\title{
ANXIETY AND DEPRESSION IN ONCOLOGY PATIENTS TREATED WITH CHEMOTHERAPY AND RADIATION
}

\author{
Ivona Hrkać, Marko Pavlović, Shpend Haxhibeqiri, Romana Babić, Marko Martinac, Dragan Babić \\ Faculty of Health Studies, University of Mostar, 88000 Mostar, Bosnia and Herzegovina
}

\begin{abstract}
INTRODUCTION: Diagnosis of malignant disease is one of the most difficult diagnosis and it is accompanied by social prejudice and it induces considerable fear in patients and their families. People living with malignant diseases have a greater risk of developing various psychological problems.

OBJECTIVE: Compare anxiety and depression in oncology patients treated with chemotherapy and radiation.

SUBJECTS AND METHODS: The study included 60 patients. Data were collected by means of Beck's Anxiety (BAI) and Depression (BDI-II) inventories and a general sociodemographic questionnaire at the Department for Oncology of the University Clinical Hospital Mostar.

RESULTS: Subjects from the chemotherapy group were mostly smokers and had a significantly lower economic status. Male subjects were significantly older than female subjects while female subjects had significantly higher scores on the depression inventory. There were no statistically significant differences between genders on the anxiety inventory. There wasno statistically significant correlation between the level of anxiety and depression with the incidence of hospitalisation. Subjects from the chemotherapy group scored significantly higher on the anxiety inventory. There were no statistically significant differences on the depression inventory between the study groups.

CONCLUSION: Subjects from the chemotherapy group scored significantly higher on the anxiety inventory. There were no statistically significant differences in the level of depression between the study groups.
\end{abstract}

Key words: anxiety, depression, oncology patient, treatment

Correspondence: Ivona Hrkać, master of radiologic technology

Email: ivonahrkac@gmail.com

Prof. dr. sc. Dragan Babić

Email: dragan.babic@fzs.sum.ba 